Research Article

\title{
The Effect of Emotional Control in Improving Communication Ethics of Silinda Junior High School Students
}

\author{
Nurasyah, Enny Fitriani, Edi Zulfikar \\ Department of Guidance Counseling, University Muslim Nusantara. Jalan Garu II No. 93, Medan, North \\ Sumatera, 20147, Indonesia.
}

\begin{abstract}
Our country is an Eastern country where polite culture is highly respected, but the reality is that the culture has begun to wane plus the technological advances wrongly utilized by teenagers today. When adolescence is a transitional period, their emotions are not stable. This is why teenagers are easily influenced in everything, so their ethics of communicating has faded. This study to determine the effect of emotional control in improving student communication ethics, this research is categorized into quantitative research because it is more effectively used with research data in the form of numbers - numbers. This study involves two types of variables. Free variables are Emotional Control, the dependent variable is the Ethics of Communicating. The instrument used in this research is the emotional control questionnaire test and analyzed by using descriptive statistics.
\end{abstract}

Key words: Group Guidance, Communication Ethics

\section{Introduction}

In the era of globalization nowaday, the flow of information so swiftly entered from various media, both the media television, mass media and internet. Any people without age limit freely access it without any filter. Especially with the internet flow of information is more easily obtained so that makes the way our teenagers view little by little change left the way of our ancestors as the easterners. It has a great impact on the development of student behavior.

The current phenomenon of students who should have positive behavior because they are in the process of character formation education, but along with the influence of television shows, internet, magazines, pornographic pictures and many others that are very easily accessed by teens, negative on adolescent behavior. If it is left continuously later can damage the development of the next generation of the nation. The negative impact of free information flow can already be felt on the change in student behavior. Often students do sometimes inappropriate deeds and disrespectful words to teachers and friends, through behaviors that have no ethical etiquette and from speech improperly spoken by a student.

Manners are good manners, karma, civilization, ethics (Great Dictionary of Indonesian). Communication ethics is part of one of manners and can also be interpreted as a person's behavior in everyday life that must be adapted to the nature, place, time and condition of the environment.

There are many demands within the school and community. Among them is ethics. In the first edition of the Big Indonesian Dictionary (K. Bertens: 2013: 4), Ethics is explained by distinguishing three meanings: "1) the science of what is good and what is bad and about moral rights and duties; 2) a collection of principles or values pertaining to morals; 3 ) the value of right and wrong embraced by a class or society"

Communication ethics is a summary of terms that have a sense of its own, namely norms, values, or measures of good behavior in communication activities in a community.
Basically interpersonal communication can take place both orally and in writing. Orally can occur directly (face to face), or by using media such as telephone, SMS, facebook, e-mail, and so on, Suranto (2011: 135)

\section{Theoritical Review}

\subsection{Emotional Control}

Emotional Control is the condition of someone who is in a pleasant state to be resilient and alert in facing various forms of challenge, Hernowo (2003: 205). Next, Ary Ginanjar Agustian (2007: 226) says emotion control is to keep the emotional position is always in the position of zero, or stable position. Emotional control needs to understand languages that may be higher in value than words. Furthermore, Emotional Control is the ability of power adjustment, work ductility, work attitude, and accuracy as well as speed in doing a job, Kunto Anggara (2015: 134).

From the above statement, a student is said to have been able to control emotions when each member can develop himself and overcome difficulties, especially in terms of emotional control.

In addition, there is also a way that can be exercised to train one's emotional control, Wahab (2015: 165), there are:

1. Learn to recognize emotions and avoid excessive interpretation of situations that can be emotional.To be able to interpret the objective, try asking some opinions from people about a particular situation or situation. For example, we feel that close friends are hurting our hearts, we can ask other friends whether or not our close friends talk is painful or maybe it's just our feelings that are chaotic.

2. Respond to the situation with both mind and emotion that is not excessive, proportional to the situation, and in an acceptable way to the social environment.

3. Learn to recognize, accept, and express positive emotions (glad, happy, affectionate) and negative (worry, annoyed, 
sad, angry).

4. Learn to postpone the needs of satisfaction.

\subsection{Communication Ethics}

Suranto (2011: 135) communication ethics is a summary of terms that have a separate understanding, namely norms, values, or measures of good behavior in communication activities in a community. Basically interpersonal communication can take place both spoken and written. In term of spoken language, it can be can occured directly (face to face), or by using media such as phone, SMS, facebook, email, and so on.

To keep the communication process is running well, for communication purposes can be achieved without raising the gap between individuals, it is needed ethics communicate. The easiest way to apply the ethics of interpersonal communication is, the parties involved in the communication process, even all of us as members of the community, need to pay attention to the following:

a. Local social cultural values and norms all rules,

b. Rules, already agreed customs,

c. Well-kept habits good manners

d. Ethics norms of morality and manners

e. Norms courtesy in every action

\subsection{Principles - Principles of Communication Ethics}

In the ethics of communication found six principles that are often used by people who are in a relationship communication, ie : 1) the principle of beauty, 2) the principle of equality, 3) the principle of goodness, 4) the principle of justice, 5) the principle of freedom, and 6) the principle of truth, Suranto (2011: 186)

\section{Principle of Beauty}

This beauty principle underlies everything that includes the pleasures of happy toward beauty.Based on this principle, people pay attention to values of beauty and want to reveal something beautiful in its behavior.

2. Principle of Equality

Every human being has essentially the same rights and responsibilities, resulting in a demand for equal rights between men and women, racial equality, and equality in other fields.

3. Principle of Goodness

This principle of goodness underlies the behavior of individuals to always try to do well in interacting with their environment. This principle is usually concerned with human values.

4. Principle of Justice

The notion of justice is a permanent and eternal to give everyone what they ought to earn.

5. Principle of Freedom

Freedom can be interpreted as the individual's freedom to act or not to act in accordance with his own choice. In the principle of life and human rights, every human being has the right to do something according to his own will so long as it does not harm or interfere with the rights of others.

6. Principle of Truth

Truth is usually used in the logic of science arising from the logical / rational thought. Truth must be proven and demonstrated, so that truth can be believed by individuals and society.

\section{Results and Discussion}

\subsection{Population and Sample of Research}

Population in this research is all student of class VIII SMP Silinda consisted 25 students which is categorized as agent of emotional control. The subjects in this study were 25 students using total sampling technique.

\subsection{Research Design}

The research design used in this research is a quantitative approach with correlational method. Correlational method is used to detect the extent of variations in a factor related to variations in one or more other factors based on the correlation coefficient (Suryabrata, 2006). In this study, researchers wanted the influence of emotional control in improving communication ethics.

Data collection is done through questionnaires given to students. Arikunto (2006: 151) says that "the scale or questionnaire is a number of written statements used to obtain information from respondents, which consists of a questionnaire of emotional control and a questionnaire of communication ethics. To assess students' answers the Likert scale is used as follows:

\begin{tabular}{|c|c|c|c|c|}
\hline \multirow{2}{*}{$\begin{array}{l}\mathbf{N} \\
\mathbf{0}\end{array}$} & \multicolumn{2}{|c|}{ Positive Question } & \multicolumn{2}{|c|}{ Negative Question } \\
\hline & Score & Description & Score & Description \\
\hline 1 & 5 & Very Agree & 1 & Very Agree \\
\hline 2 & 4 & Agree & 2 & Agree \\
\hline 3 & 3 & Less Agree & 3 & Less Agree \\
\hline 4 & 2 & Disagree & 4 & Disagree \\
\hline 5 & 1 & $\begin{array}{l}\text { Strongly } \\
\text { Disagree }\end{array}$ & 5 & $\begin{array}{l}\text { Strongly } \\
\text { Disagree }\end{array}$ \\
\hline
\end{tabular}

Table3.1: Getting Score Question Based on LikertScale

Ket:

Scale 4 : Very Agree (VA)

Scale 3 : Agree (A)

Scale 2 : Disagree (D)

Scale 1 : Strongly Disagree (SD)

\subsection{Descriptive Data Research Result}

\subsubsection{Test Validity of Emotional Control}

Based on the results calculation of correlation coefficient, for the questionnaire of emotional control number 1 obtained $r_{x y}=$ 0,595 at significant level $\alpha=5 \%$ and $\mathrm{N}=25$ obtained $\mathrm{r}_{\text {table }}$ value $=0.396$. Then from the results can be seen that $r_{x y}>r_{\text {table }}$ is $0,595>0,396$ as well as the questionnaire items ethical communication number $1 \mathrm{r}_{\mathrm{xy}}>\mathrm{r}_{\text {table }}$ is $0,562>0,396$. So it can be concluded that the item number 1 is declared valid. The example of the calculation from item number 1 is as follows:

$$
\begin{aligned}
& r_{x y}=\frac{n \sum X Y-\sum X \sum Y}{\sqrt{\left\{n \sum X^{2}-\left(\sum X\right)^{2}\right\}\left\{n \sum Y^{2}-\left(\sum Y\right)^{2}\right\}}} \\
& r_{x y}=\frac{(25 \times 9264)-(70 \times 3232)}{\sqrt{\left\{(25 \times 216)-(70)^{2}\right\}\left\{(25 \times 424334)-(3232)^{2}\right\}}} \\
& r_{x y}=\frac{5360}{\sqrt{81263000}}
\end{aligned}
$$

\subsection{Data Collection Techniques}


$\mathrm{r}_{\mathrm{xy}} \quad=\frac{5360}{9015}$

$\mathrm{r}_{\mathrm{xy}} \quad=0,595$

\subsubsection{Test Reliability Emotional Control}

Based on the results of reliabilitycalculation, questionnaire that uses the Spearman Brown formula halves even-odd, it is known that the value of $\mathrm{r} 11=0.988$ and after consultation with the correlation index included in the high category. So it can be concluded that the questionnaire of students' emotional control and communication ethics fulfill the criteria of reliability so that it can be used as a means of data collection. The value of emotional control reliability used the alpha formula is as follows:

$\mathrm{r} 11=\left[\frac{\mathrm{k}}{\mathrm{k}-1}\right]\left[1-\frac{\sum \sigma \mathrm{b}^{2}}{\sigma \tau^{2}}\right]$

$\mathrm{r} 11=\left[\frac{45}{45-1}\right]\left[1-\frac{22,6}{796,26}\right]$

$\mathrm{r} 11=\left[\frac{45}{44}\right][1-0,033]$

$\mathrm{r} 11=1,025 \cdot 0,967$

$\mathrm{r} 11=0,988$

\subsubsection{Test of Validity of Communication Ethics}

Based on the calculation of correlation coefficient, for questionnaire ethical communication number 1 obtained $\mathrm{r}_{\mathrm{xy}}=$ 0,562 at significant level $\alpha=5 \%$ and $\mathrm{N}=25$ obtained $\mathrm{r}_{\text {table }}$ value $=0.396$ further from result it can be seen that $r_{x y}>r_{\text {table }}$ is $0,562>0,396$. The example of calculation from item number 1 is as follows:

$$
\begin{aligned}
r_{x y}= & \frac{n \sum X Y-\sum X \sum Y}{\sqrt{\left\{n \sum X^{2}-\left(\sum X\right)^{2}\right\}\left\{n \sum Y^{2}-\left(\sum Y\right)^{2}\right\}}} \\
r_{x y} & =\frac{(25 \times 8902)-(77 \times 2849)}{\sqrt{\left\{(25 \times 247)-(77)^{2}\right\}\left\{(25 \times 329795)-(2849)^{2}\right\}}} \\
r_{x y} & =\frac{3177}{\sqrt{31890426}} \\
r_{x y} & =\frac{3177}{5647} \\
r_{x y} & =0,562
\end{aligned}
$$

\subsubsection{Reliability Test Ethics Communication}

Reliability value of communication ethics used the alpha formula is as follows:

$$
\begin{aligned}
\mathrm{r} 11 & =\left[\frac{\mathrm{k}}{\mathrm{k}-1}\right]\left[1-\frac{\sum \sigma \mathrm{b}^{2}}{\sigma \tau^{2}}\right] \\
\mathrm{r} 11 & =\left[\frac{40}{40-1}\right]\left[1-\frac{23,18}{639,01}\right] \\
\mathrm{r} 11 & =\left[\frac{40}{39}\right][1-0,036] \\
\mathrm{r} 11 & =1,025 \cdot 0,964 \\
\mathrm{r} 11 & =0,988
\end{aligned}
$$

\subsubsection{Calculation of Interconnection Correlation Coefficient}

To calculate the correlation coefficient between research variables used product moment formula as follows:

$$
r_{x y}=\frac{n \sum X Y-\left(\sum X\right)\left(\sum Y\right)}{\sqrt{\left\{n \sum X^{2}-\left(\sum X\right)^{2}\right\}\left\{n \sum Y^{2}-\left(\sum Y\right)^{2}\right\}}}
$$

From the calculation obtained results as follows:

$$
\begin{aligned}
\sum X & =3232 & & ; \sum X^{2}=424334 \\
\sum Y & =2849 & & ; \sum Y^{2}=329795 \\
\sum X Y & =374029 & & \\
N & =25 & &
\end{aligned}
$$

By entering the results into the formula, it is obtained:

$$
\begin{aligned}
& r_{x y}=\frac{25(374029)-(3232)(2849)}{\sqrt{\left\{25(424334)-(3232)^{2}\right\}\left\{25(329795)-(2849)^{2}\right.}} \\
& r_{x y}=\frac{9350725-9207968}{\sqrt{\{(10608350-10445824)(8244875-8116801)}\}}
\end{aligned}
$$$$
r_{x y}=\frac{142757}{\sqrt{\{(162526)(128074)\}}}
$$$$
r_{x y}=\frac{142757}{\sqrt{208153549 y}}
$$

$$
\begin{aligned}
r_{x y} & =\frac{142757}{14427527} \\
& =0,989
\end{aligned}
$$

To find out if $r_{x y}=0.989$ is significant or not, consult the interpretation table of the value of " $r$ " product moment below.

\begin{tabular}{|l|l|}
\hline $\begin{array}{l}\text { The Amount of } \\
\text { "r" } \\
\text { product moment } \\
\text { (rxy) }\end{array}$ & Interpretation \\
\hline $0,00-0,20$ & $\begin{array}{l}\text { Between variables X and Y there is } \\
\text { correlation, but the correlation is very } \\
\text { weak and very low so correlation it is } \\
\text { ignored (assumed there is no } \\
\text { correlation between variables } X \text { and } \\
\text { Y) }\end{array}$ \\
\hline $0,20-0,40$ & $\begin{array}{l}\text { Between variables X and Y there is a } \\
\text { weak or low correlation }\end{array}$ \\
\hline $0,40-0,60$ & $\begin{array}{l}\text { Between variables X and Y there is } \\
\text { moderate or moderate correlation }\end{array}$ \\
\hline $0,60-0,80$ & $\begin{array}{l}\text { Between the variables } X \text { and Y there } \\
\text { is a strong correlation or high }\end{array}$ \\
\hline $0,80-1,00$ & $\begin{array}{l}\text { Between the variables X and Y there } \\
\text { is a very strong correlation or very } \\
\text { high }\end{array}$ \\
\hline
\end{tabular}

Table3.2: Interpretation of "r" Value Product Moment Arikunto (2010 : 276)

Based on the r-theoritical table with $\mathrm{N}=25$, known $\mathrm{r}_{\text {table }}$ value at raf $5 \%=0.396$ and at the level of $1 \%=0.263$. Thus it is known that the results $r_{\text {test }}>r_{\text {table }}$ or $0.989>0.396$ and $0.989>$ 0.263 both at the level of significance of $5 \%$ and $1 \%$ and stated significant. When seen the amount of $r_{x y}$ is 0.989 adjusted to the interpretation value of " $r$ " product moment in 
the above table between 0.80 to 1.00 , with the category strong or very high. It can be concluded that there is correlation or influence between variable $\mathrm{x}$, that is emotional control and variable $\mathrm{y}$, that is student communication ethics.

\section{Conclusion and Suggestion}

\subsection{Conclusion}

Based on the research result, it can be concluded that contribution group guidance to student emotional control in improving communication ethics. This is seen before getting guidance group emotional control MAS Lab IKIP AlWashliyah is in the category of low and medium and after the guidance of their emotional control group changed in high category.

\subsection{Suggestion}

Based on the above conclusions, then as follow up this research suggested things as follows:

1. Suggestions For Guidance Counselling (GC) Teachers

Guidance conselling teachers provide group guidance services with more regular and systematic to help students to be better able to control the emotions themselves because the control of good emotions will help determine the success of students.

2. Suggestions for Other Researchers

To the other researchers pay attention to the students' emotional control, in order to consider other factors that have a relationship with emotional control and student communication ethics such as family factors, peers, selfcontrol, residential environment.

3. Suggestions for Research Subjects

Given the finding that there is a group guidance contribution to student emotional control in improving the communication ethics, it is advisable to students with moderate and moderate emotional control to follow regular and serious group guidance services, avoiding association with rogue friends, poor environment.

\section{References}

[1] Arikunto, Suharsimi, 2006. Prosedur Penelitian Suatu Pendekatan Praktik. Jakarta : Rineka Cipta

[2] Ary Ginanjar, 2003, ESQ Power,Jakarta: Arga.

[3] AW. Suranto. 2011. Komunikasi Interpersonal. Yogyakarta. Graha Ilmu

[4] Dawson dalam Triatna dan Kharisma (2008:25) Journal Formatif S(1): 26:41, 2015 ISSN: 2088-35IX

[5] Goleman (2015) dalan Journal Ilmiah Cisoc Vol II No.2 2016/ISSN 2460-1802

[6] Hartinah, Sitti. 2009. Konsep Dasar Bimbingan Kelompok Bandung: PT Refika Aditama.

[7] Lahmuddin, 2006, Konsep-konsep Dasar Bimbingan dan Konseling, Bandung;Citapustaka Media.

[8] Prayitno, Amti Erman. 2008. Dasar-dasar Bimbingan dan Konseling. Jakarta: Rineka Cipta.

[9] Prayitno. 2012. Seri Panduan Layanan dan kegiatan Pendukung Konseling. Padang: Universitas Negeri Padang.

[10] Santoso AS. 2008. Modul 10 Kepribadian dan Emosi. Universitas Mercu Buana

[11] Tohirin. 2007. Bimbingan dan Konseling di Sekolah dan Madrasah(Berbasis Integrasi).Jakarta: P.T RajaGrafindo Persada 